\title{
Italian universities 'must be more efficient'
}

Munich. Italy's parliament has welcomed proposals by the new science minister, Umberto Colombo, to reform the country's disorderly universities. Although time is not on Colombo's side - the interim government will be replaced in a general election next spring or even sooner his forthcoming three-year plan may well set the agenda for the incoming government.

Italy's universities face several major problems. Although they produce a few excellent scientists, says Colombo, the general standard is low. Costs in many universities have soared unreasonably; cost effectiveness can vary twelvefold between campuses. Many universities are also seriously overcrowded, and the average dropout rate (64 per cent) is almost double that of other large European countries.

"We need to apply a magnetic field to the disorderly world of university research," says Colombo, whose full title is minister first to think so: successive governments have attempted to reform the university system with little success. Italians are now impatient for change, not just prepared to tolerate it; and for the first time real reform seems possible. Nevertheless, Colombo is proceeding carefully: "If you push too hard against resistance, in a few years everything will return to how it is now."

One of Colombo's reforms would be to make universities more responsible for their spending. He would let them manage their entire budget, and provide funding as a lump sum instead of on an item-by-item basis. He intends this to stimulate greater

\section{IMAGE UNAVAILABLE FOR COPYRIGHT REASONS} for universities and research. He is not the

cost effectiveness. It would also mean that universities that overspend could be penalized. "We do not intend to continue funding inefficiency," says Colombo.

If universities have to be seen to be acting efficiently, he says, the problem of the much criticized system of appointing professors, which is alleged to lead to fixing, might also disappear.

$\mathrm{He}$ also wants to slash the generous subsidies universities enjoy: "we can no longer afford them". Such subsidies also contribute to the problems of overcrowding and high drop-out rates: many students go to university because they will be better off than if unemployed - fees are cheap and they benefit from highly subsidized facilities such as canteens. Young people sometimes use universities "like parking lots", says Colombo, using an analogy well worn by exasperated academics.

The major problem facing university research is unfair distribution of public funding. The state provides money for fundamental (60 per cent) and applied research

\section{Time runs out in space research dispute}

Munich. A deadlock between the board and scientific committee of the Italian space agency (ASI), which has resulted in no research funds being given for almost two years, will die a natural death next week when the board is disbanded at the end of its five-year term.

Ultimate responsibility for the mess lies with the former government which failed to take decisive action to restore order, says Umberto Colombo, research minister in Italy's interim government. But ASI's board and scientific committee were also at fault, he says.

One of the main reasons for the deadlock was an argument over what proportion of the budget should be spent on national space programmes and what on contributions to the programmes of the European Space Agency (ESA). Escalating internal feuds ended up in court, but researchers have still received no funding.

The board, says Colombo, should have consulted the scientific committee on decisions involving ESA: the committee argued that ASI's commitments to ESA were a drain on national programmes. The scientific committee should also have been more wanted to fragment funding too much.

But the main problem was simply one of bad management. By law, the chairperson and director of ASI must be expert scientists. Colombo believes expertise in strategic management would be a more helpful qualification if ASI is to avoid similar mistakes in future.

A new board will be a critical opportunity for change, says Colombo. Italy, he says, will be more selective about space research in future. ASI's unrealistic promises overstretched budgets. Italy will now support the trend in Europe towards a deceleration of the space programme combined with greater international collaboration.

Alison Abbott selective in giving out grants, he says: they
(40 per cent) either directly or via national research councils. But the National Universities Council's 12 discipline-orientated review committees lack a formal referee system and appropriate post hoc evaluation. They try to keep everybody happy by giving each a little money.

Bad enough for basic research, but a disaster for applied research, says Colombo, who wants to introduce conventional refereeing and formal evaluation. Money for applied research should be divided with clearly defined priorities in mind, he believes. "You can't tackle big problems such as climate research with small grants to individuals."

The National Institute of Nuclear Physics, which deals with subnuclear and high-energy physics, has always done very well. Its success proves some things can work well in Italy, says Colombo. But it will not be so generously funded in future; more money must be made available for other research areas of more direct relevance to the Italian economy which have not received as much attention.

Colombo also wants more collaboration between universities and industry. It can work. In the $1950 \mathrm{~s}$, scientists at the Polytechnic of Milan (led by Giulio Natta, the 1963 Nobel prizewinner in chemistry) and the Montecatini company developed polypropylene in Italy; more than onehundred of the company's staff worked for years as researchers at the polytechnic.

But this unfortunately is an isolated success story. Corruption has shattered large industry, and the hundreds of thousands of small companies in Italy have little interest in research: they prefer to redesign products developed elsewhere.

"We hope the new wave of morality and rebellion in the country will encourage the universities to act," says Colombo. But the universities are constitutionally independent, and he realizes that besides making them financially responsible he can only cajole them into change. Colombo lives each day as if he were minister for life, he says, while ready to pack his bags at any moment. That's life in Italy now.

Alison Abbott 